\title{
Post-evaluation Method and Application of Green Campus
}

\author{
Hui Guo ${ }^{1, a}$, Xiaoping Feng ${ }^{* 2, b}$, Yilin Ding ${ }^{3, c}$, Bailu Ma ${ }^{4, d}$, Chunping Wang ${ }^{5, e}$, \\ Xiaoxia Lu, ${ }^{6, f}$
}

School of Environment and Civil Engineering, Jiangnan University, 1800 Lihu Avenue, Wuxi, China

ajndxgh2014@163.com, bx fxp99@126.com

Keywords: green campus, post-evaluation, index system, multi-level grey evaluation method.

Abstract. The paper is intended to create a relatively simple and clear post-evaluation system for green campus. From the aspects of planning and ecology, energy and resources, environment and health, operation and management, education and promotion, by use of the analytic hierarchy process, the paper aims to determine the weight, build a model and establish a post-evaluation system for green campus. With Jiangnan University as an example, adopting multi-level grey evaluation method, the paper makes an evaluation of Jiangnan University and gains according star grade.

\section{Introduction}

Green campus is referring to a cultural environment oriented toward green, environmental protection and sustainable development and aimed at saving energy, land, water, material and protecting environment within the life cycle of campus under the condition of ensuring its fundamental education function. ${ }^{\text {[1] }} \mathrm{Up}$ till now, there have been approximately four thousand institutions for higher learning all around the nation, whose energy consumption accounts for a large portion of the total of the society. However, China's construction of green campus is basically remaining at the level of conception without any large-scale practice and promotion. In order to boost the development of green campus and help construction of green campus ascend to practice from conceptual level, it is essential to build a complete evaluation index system to appraise and direct institutions of higher learning. For realizing the purpose of guiding the construction of green campus, China has attempted to establish several sets of evaluation standards for green campus. Nevertheless, by contrast with international-mature evaluation system for green campus, domestic evaluation standard is not as complete, and the practice and application is not as much. To accelerate Chinese construction of green campus, it is necessary to set up a scientific and effective post-evaluation system in line with national conditions.

\section{Evaluation index system for green campus}

\section{Fundamental principles for establishing index system}

Principle of scientificity

Selection of post-evaluation index for green campus shall follow the principle of objectivity and be based on theory of sustainable development and theory of economic applicability. The definition, computing method, data collection, coverage range and weight selection of scientific index shall be performed on scientific basis so as to enable index system to withstand repeat scrutiny and give expression to the nature and features of green campus to the best for the purpose of being applied extensively $^{\mathbf{2} 2 \mathbf{1}}$.

Principle of systematization

On account of the complexity of post-evaluation system for green campus, the establishment of system should comply with principles of systematization and hierarchy to realize both independence and connection between indexes in order to make a systematic evaluation to colleges and universities from the aspects of planning, emerging saving, operation management, education and promotion.

Principle of operability 
Principle of operability requires that the finalized index system can be fully used and applied, and that the selected indexes can receive reliable evaluation. In addition, it is essential to screen these indexes to select out those which are representative enough to lead the construction of green campus in colleges and universities.

Principle of comparability

To serve as an evaluation system, in order to acquire objective and effect assessment results, it is necessary to ensure that the indexes are quantizable, which on one hand, requires that the qualitative indexes can be indirectly quantized after being assigned, and on the other hand, means that quantitative indexes can be quantized directly. Quantifiability is a major factor to ensure the comparability of evaluation system.

\section{Establishment of evaluation index system for green campus}

According to the principles of comprehensiveness and systematization, select a number of factors as the first-level evaluation index, including the influence of environment and health, planning and ecology, operation and management, education and promotion, etc. on the construction of green campus, which summarizes all the factors influencing the construction of green campus. Each first-level contains lots of second-level indexes, and the like till the indexes are measurable and can reflect the overall state as detailly and roundly

Table 1: Post-evaluation index system for green campus

\begin{tabular}{|c|c|c|c|}
\hline & First-level index & Second-level index & Third-level index \\
\hline \multirow{30}{*}{$\begin{array}{l}\text { Evaluation Index } \\
\text { System for } \\
\text { Green Campus }\end{array}$} & \multirow{6}{*}{$\begin{array}{l}\text { Planning and } \\
\text { Ecology }\end{array}$} & \multirow{2}{*}{$\begin{array}{l}\text { Land saving and } \\
\text { Greening }\end{array}$} & Land Utilization \\
\hline & & & Land for Greening \\
\hline & & \multirow{2}{*}{ Safety Planning } & Urgent Evacuation System \\
\hline & & & Setting of Guide Sign \\
\hline & & \multirow{2}{*}{ Traffic Planning } & Setting of Parking Lot \\
\hline & & & Public Traffic Networks \\
\hline & \multirow{7}{*}{$\begin{array}{l}\text { Energy and } \\
\text { Resources }\end{array}$} & \multirow{2}{*}{ Energy Consumption } & $\begin{array}{c}\text { Students' Average Energy } \\
\text { consumption }\end{array}$ \\
\hline & & & $\begin{array}{l}\text { Students' Average Water } \\
\text { consumption }\end{array}$ \\
\hline & & \multirow{2}{*}{$\begin{array}{c}\text { Energy Efficiency } \\
\text { Optimization }\end{array}$} & Water Saving of Equipment \\
\hline & & & Energy Saving of Equipment \\
\hline & & \multirow{3}{*}{$\begin{array}{c}\text { Non-traditional } \\
\text { Resources Utilization }\end{array}$} & Recycle of Renewable Energy \\
\hline & & & Recycle of Rainwater \\
\hline & & & Middle-water System \\
\hline & \multirow{8}{*}{$\begin{array}{l}\text { Environment and } \\
\text { Health }\end{array}$} & \multirow{2}{*}{$\begin{array}{c}\text { Environmental Comfort } \\
\text { Level }\end{array}$} & Acoustic Environment \\
\hline & & & Thermal and Humid Environment \\
\hline & & \multirow{3}{*}{ Outdoor Environment } & Surface Water Environment \\
\hline & & & Green Environment \\
\hline & & & Outdoor Wind Environment \\
\hline & & \multirow{3}{*}{$\begin{array}{c}\text { Health of Teachers and } \\
\text { Students }\end{array}$} & Heath Education \\
\hline & & & Health-care Equipment \\
\hline & & & Public Health \\
\hline & \multirow{5}{*}{$\begin{array}{l}\text { Operation and } \\
\text { Management }\end{array}$} & \multirow{2}{*}{ Technical Management } & Equipment Management \\
\hline & & & Intellectualized System \\
\hline & & \multirow{3}{*}{$\begin{array}{c}\text { Environmental } \\
\text { Management }\end{array}$} & Greening Maintenance \\
\hline & & & Refuse Disposal \\
\hline & & & Pollutant Emission \\
\hline & \multirow{4}{*}{$\begin{array}{l}\text { Education and } \\
\text { Promotion }\end{array}$} & \multirow{2}{*}{ Publicity and Promotion } & Propaganda \\
\hline & & & Course Setting \\
\hline & & \multirow{2}{*}{$\begin{array}{c}\text { Achievements in } \\
\text { Scientific Research }\end{array}$} & $\begin{array}{c}\text { Technology Research and } \\
\text { Development }\end{array}$ \\
\hline & & & Award and Praise \\
\hline
\end{tabular}




\section{Planning and ecology}

The index is used to evaluate the overall planning and ecological environment of campus. Campus planning is a determinant factor to campus' future plasticity and overall style, including land saving and greening, safety planning, traffic planning and filed construction.

Energy and Resources

The index of energy and resources is applied to assess campus' overall effect of energy saving. In respect to utilization of energy and resources, institutions of higher learning are supposed to keep in line with the principle of sustainable development and serve as an example to influence their surroundings in the aspect of energy saving and utilization of sustainable resources. The index is made up of resources consumption, energy efficiency optimization and use of non-traditional energy and puts emphasis on the principle of sustainable development and rational utilization of resources.

Environment and health

The index is adopted to evaluate the overall environment of campus. Campus environment will greatly impact the comfort of the major groups, teachers and students. Favorable campus environment is able to provide both teachers and students with pleasant feelings and has positive effects on their working and learning. Environment and health contains acoustic environment, thermal and humid environment, outdoor environment and safeguard measures for teachers' and students' health.

Operation and management

As a whole, campus needs to be equipped with a complete operation and management system, which is roughly divided into system management, technical management and environment and used to observe operation and management effect and whether management system is complete.

Education and promotion

During constructing green campus, institutions of higher learning should get the utmost out of its major functions and features, formulate related regulations and policies, implement education and promotion, research and popularize relevant results in scientific research so as to push forward nationwide construction of green campus. The items of evaluation include times of activities about the construction of green campus, total number of participants and the number of technology research and development projects about the construction of green campus.

\section{Weight determination}

After finishing the establishment of evaluation model for green campus, it is required to distribute weight to all levels of evaluation indexes so as to work out the total points of items according to the score of indexes, thus to determine campus's stars. In terms of weight determination, there are usually two categories, namely subject weighting evaluation method and object weighting evaluation method.

Post-evaluation system for green campus, a multi-level and multi-factor evaluation system, not only involves energy saving and environmental protection of equipment inside campus, but reflects the main users' satisfaction with the overall environment, filed and traffic planning, facilities and equipment management, operation and promotion of green campus. Therefore, to evaluate green campus is a comparatively blurry process difficult to be quantified accurately. The paper adopts the analytic hierarchy process in subject weighting evaluation method to determine weight. In addition, in order to improve accuracy of calculation, the case applies analytic hierarchy process software, YAAHP, as a tool to calculate the weight and gains the weight of all levels of indexes as below. 
Table 2: Weight of all levels of indexes

\begin{tabular}{|c|c|c|c|c|c|}
\hline $\begin{array}{l}\text { First-level } \\
\text { index }\end{array}$ & Weight & Second-level index & Weight & Third-level index & Weight \\
\hline \multirow{6}{*}{$\begin{array}{l}\text { Planning and } \\
\text { Ecology }\end{array}$} & \multirow{6}{*}{0.2000} & \multirow{2}{*}{$\begin{array}{l}\text { Land saving and } \\
\text { Greening }\end{array}$} & \multirow{2}{*}{0.3332} & Land Utilization & 0.4565 \\
\hline & & & & Land for Greening & 0.5435 \\
\hline & & \multirow{2}{*}{ Safety Planning } & \multirow{2}{*}{0.3591} & $\begin{array}{c}\text { Urgent Evacuation } \\
\text { System } \\
\end{array}$ & 0.4975 \\
\hline & & & & Setting of Guide Sign & 0.5025 \\
\hline & & \multirow{2}{*}{ Traffic Planning } & \multirow{2}{*}{0.3077} & Setting of Parking Lot & 0.4924 \\
\hline & & & & Public Traffic Networks & 0.5076 \\
\hline \multirow{7}{*}{$\begin{array}{l}\text { Energy and } \\
\text { Resources }\end{array}$} & \multirow{7}{*}{0.2500} & \multirow{2}{*}{ Energy Consumption } & \multirow{2}{*}{0.3333} & $\begin{array}{l}\text { Students' Average } \\
\text { Energy consumption }\end{array}$ & 0.5128 \\
\hline & & & & $\begin{array}{c}\text { Students' Average Water } \\
\text { consumption }\end{array}$ & 0.4872 \\
\hline & & \multirow{2}{*}{$\begin{array}{l}\text { Energy Efficiency } \\
\text { Optimization }\end{array}$} & \multirow{2}{*}{0.3333} & $\begin{array}{c}\text { Water Saving of } \\
\text { Equipment }\end{array}$ & 0.4975 \\
\hline & & & & $\begin{array}{l}\text { Energy Saving of } \\
\text { Equipment }\end{array}$ & 0.5025 \\
\hline & & \multirow{3}{*}{$\begin{array}{c}\text { Non-traditional } \\
\text { Resources } \\
\text { Utilization }\end{array}$} & \multirow{3}{*}{0.3334} & $\begin{array}{c}\text { Recycle of Renewable } \\
\text { Energy }\end{array}$ & 0.3737 \\
\hline & & & & Recycle of Rainwater & 0.3241 \\
\hline & & & & Middle-water System & 0.3022 \\
\hline \multirow{8}{*}{$\begin{array}{l}\text { Environment } \\
\text { and Health }\end{array}$} & \multirow{8}{*}{0.2500} & \multirow[b]{2}{*}{$\begin{array}{l}\text { Environmental } \\
\text { Comfort Level }\end{array}$} & \multirow[b]{2}{*}{0.3203} & Acoustic Environment & 0.4924 \\
\hline & & & & $\begin{array}{c}\text { Thermal and Humid } \\
\text { Environment }\end{array}$ & 0.5076 \\
\hline & & \multirow{3}{*}{$\begin{array}{c}\text { Outdoor } \\
\text { Environment }\end{array}$} & \multirow{3}{*}{0.3121} & $\begin{array}{c}\text { Surface Water } \\
\text { Environment }\end{array}$ & 0.3201 \\
\hline & & & & Greening Environment & 0.3604 \\
\hline & & & & $\begin{array}{c}\text { Outdoor Wind } \\
\text { Environment }\end{array}$ & 0.3195 \\
\hline & & \multirow{3}{*}{$\begin{array}{l}\text { Health of Teachers } \\
\text { and Students }\end{array}$} & \multirow{3}{*}{0.3676} & Heath Education & 0.3254 \\
\hline & & & & Health-care Equipment & 0.3298 \\
\hline & & & & Public Health & 0.3448 \\
\hline \multirow{5}{*}{$\begin{array}{c}\text { Operation } \\
\text { and } \\
\text { Management }\end{array}$} & \multirow{5}{*}{0.2000} & \multirow{2}{*}{$\begin{array}{c}\text { Technical } \\
\text { Management }\end{array}$} & \multirow{2}{*}{0.5192} & Equipment Management & 0.4444 \\
\hline & & & & Intellectualized System & 0.5556 \\
\hline & & \multirow{3}{*}{$\begin{array}{l}\text { Environmental } \\
\text { Management }\end{array}$} & \multirow{3}{*}{0.4808} & Greening Maintenance & 0.3509 \\
\hline & & & & Refuse Disposal & 0.3229 \\
\hline & & & & Pollutant Emission & 0.3262 \\
\hline \multirow{4}{*}{$\begin{array}{l}\text { Education } \\
\text { and } \\
\text { Promotion }\end{array}$} & & Publicity and & & Propaganda & 0.5039 \\
\hline & & Promotion & 0.5000 & Course Setting & 0.4961 \\
\hline & 0.1000 & Achievements in & 0.5000 & $\begin{array}{c}\text { Technology Research } \\
\text { and Development }\end{array}$ & 0.5238 \\
\hline & & & & Award and Praise & 0.4762 \\
\hline
\end{tabular}




\section{Establish evaluation index set}

Let $U$ be evaluation index set, among which (referring to number i first-level evaluation index) is the first-level index set, ( referring to number $\mathrm{j}$ second-level evaluation index under number $\mathrm{i}$ first-level evaluation index), ( referring to number $\mathrm{k}$ third-level index under number $\mathrm{j}$ second-level index contained in number i first-level evaluation index).

\section{Produce scoring standard and determine the weight of all indexes}

Since evaluation index usually belongs to the range of subject index, it is required to quantify evaluated items and make evaluation. The paper adopts the pattern of scoring by experts in order to distinguish

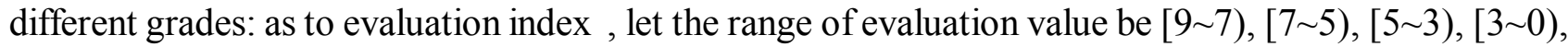
corresponding to the grades of evaluated items with three stars, two stars, one star and below grade respectively. For the weight of indexes, see Table 4.

\section{Organize experts to grade and build sample matrix}

After the weight of indexes is determined, invite p experts to grade the evaluated objects based on all listed indexes in the three levels according to the given scoring standard within the range of [0 9]. Calculate the score and then put the result into sample matrix:

In the matrix, refers to the score of evaluation index given by expert $\mathrm{p}$.

\section{Determine evaluation grey class}

Determining evaluation grey class is to confirm its number of grades, the corresponding grey number and whitenization weight function. In accordance with the scoring standard, divide evaluation grey class into four levels, namely, e=1, 2, 3, 4, whose corresponding grey number and whitenization weight function are presented as below.

Table 3

\begin{tabular}{|c|c|c|c|c|}
\hline Grey class & Grey number & \multicolumn{3}{|c|}{ Whitenization Weight Function $f_{e}$} \\
\hline $\begin{array}{l}\text { Three-star } \\
\qquad(\mathrm{e}=1)\end{array}$ & $\otimes_{1} \in[9,7)$ & $f_{1}\left(d_{i j k}\right)=$ & $\left\{\begin{array}{c}\frac{1}{9} d_{i j k} \\
1 \\
0\end{array}\right.$ & $\begin{array}{c}0 \leq d_{i j k} \leq 9 \\
d_{i j k}>9 \\
\text { Others }\end{array}$ \\
\hline $\begin{array}{l}\text { Two-star } \\
(\mathrm{e}=2)\end{array}$ & $\otimes_{2} \in[7,5)$ & $f_{2}\left(d_{i j k}\right)=$ & $\begin{array}{c}\frac{1}{7} d_{i j k} \\
14-d_{i j k} \\
7 \\
0\end{array}$ & $\begin{array}{c}0 \leq d_{i j k} \leq 7 \\
7<d_{i j k} \leq 14 \\
\text { Others }\end{array}$ \\
\hline $\begin{array}{l}\text { One-star } \\
(\mathrm{e}=3)\end{array}$ & $\otimes_{3} \in[5,3)$ & $f_{3}\left(d_{i j k}\right)=$ & $\begin{array}{c}\frac{1}{5} d_{i j k} \\
10-d_{i j k} \\
5 \\
0\end{array}$ & $\begin{array}{c}0 \leq d_{i j k} \leq 5 \\
5<d_{i j k} \leq 10 \\
\text { Others }\end{array}$ \\
\hline $\begin{array}{l}\text { Unqualified } \\
\qquad(\mathrm{e}=4)\end{array}$ & $\otimes_{4} \in[3,0)$ & $f_{4}\left(d_{i j k}\right)=$ & $\left\{\begin{array}{c}1 \\
6-d_{i j k} \\
3 \\
0\end{array}\right.$ & $\begin{array}{c}0 \leq d_{i j k} \leq 3 \\
3<d_{i j k} \leq 6 \\
O \text { thers }\end{array}$ \\
\hline
\end{tabular}




\section{Apply matrix operation to make an overall evaluation of all levels of indexes}

Let the whitenization weight function of the third-level index $U_{i j k}$ under number e grey class be $x_{i j k e}=\sum_{k=1}^{p} f_{e}\left(d_{i j k e}\right)$, the total evaluation coefficient of that belonging to every grey class $\mathrm{X}_{\mathrm{ijk}}=\sum_{\mathrm{e}=1}^{4} \mathrm{x}_{\mathrm{ijke}}$. Let the whitenization weight coefficient vector of the third evaluation index $U_{\mathrm{ijk}}$ be $r_{i j k}=\left(r_{i j k 1}, r_{i j k 2}, r_{i j k 3}, r_{i j k 4}\right)^{T}$, among which $r_{i j k e}=\frac{x_{i j k e}}{x_{i j k}}$. Based on $r_{i j k}$, build a whitenization weight coefficient matrix of the third-level index $R_{i j}=\left[r_{i j 1}, r_{i j 2}, L, r_{i j k}\right]$, and make a comprehensive assessment of $U_{i j k}: B_{i j}=w_{i j} * R_{i j}$. Based on $B_{i j}$, establish a whitenization weight coefficient matrix of the second-level index $R_{i}=\left[B_{i 1}, B_{i 2}, L, B_{i j}\right]$. Make an overall evaluation of $U_{i j}$ as $B_{i}=W_{i} * R_{i}$ and create a whitenization weight coefficient matrix of the first-level index $R=\left[B_{1}, B_{2}, L, B_{i}\right]$ based on $B_{i}$. Make a comprehensive evaluation of $U_{i}$ and reach the result $\mathrm{B}=\mathrm{W} * \mathrm{R}$.

At last, suppose the valued vector of evaluation grey class as $C=(9,7,5,3)$, and make an overall assessment of target $\mathrm{S}$ with the result $\mathrm{G}=\mathrm{B} *(9,7,5,3)^{\mathrm{T}}$. According to the final result $\mathrm{G}$ and the given scoring standard, three stars [9 7), two stars [7 5), one star [5 3), under grade [3 0), it comes to the final result.

\section{Case analysis}

Jiangnan University is situated in Wuxi City, Jiangsu Province and directly under the Ministry of Education. The campus covers an area of 3,125mu with a floorage of more than $1,000,000$ square meters. In 2008, Jiangnan University proposed the target of establishing low carbon and green campus and bettering water saving and energy saving. In addition, the university independently developed and designed a "digital energy supervision" platform, which comprises of electric power measurement, water supply measurement, smart lighting, fire control and other monitoring sub-systems and achieved scientific management and efficient energy saving by an integrated application of cutting-edge technologies including network, communication, information, control, etc. what's more, the school has set up specialized an organization to oversee the power consumption of major buildings. Besides, the university has carried forward energy saving and cost reducing by real-time monitoring of the water supply and drainage pipeline network through nearly 20,000 sense monitoring points and is successful in constructing Jiangnan University as an energy-saving green campus. In the paper, Jiangnan University is taken as an example for the post-evaluation of green campus.

In combination with evaluation index system and experts' scoring, the evaluated values of all indexes are as below.

$$
\mathrm{D}^{\mathrm{T}}=\left[\begin{array}{llllllllllllllllllllllllllllll}
8 & 8 & 7 & 7 & 5 & 5 & 7 & 7 & 8 & 7 & 8 & 9 & 9 & 7 & 7 & 8 & 8 & 7 & 6 & 6 & 6 & 8 & 8 & 8 & 7 & 6 & 6 & 5 & 7 & 7 \\
9 & 9 & 7 & 6 & 7 & 6 & 8 & 8 & 8 & 8 & 9 & 9 & 9 & 6 & 7 & 8 & 9 & 6 & 7 & 7 & 7 & 8 & 9 & 9 & 8 & 7 & 5 & 6 & 7 & 6 \\
8 & 9 & 6 & 6 & 7 & 7 & 8 & 8 & 8 & 8 & 8 & 8 & 9 & 7 & 6 & 7 & 9 & 7 & 6 & 7 & 8 & 7 & 9 & 8 & 8 & 7 & 6 & 5 & 8 & 7 \\
8 & 9 & 7 & 6 & 6 & 7 & 9 & 9 & 7 & 7 & 9 & 9 & 9 & 7 & 8 & 8 & 8 & 7 & 6 & 6 & 8 & 9 & 9 & 9 & 7 & 6 & 5 & 6 & 7 & 7 \\
9 & 8 & 6 & 7 & 7 & 7 & 8 & 8 & 8 & 8 & 9 & 8 & 8 & 8 & 8 & 8 & 9 & 6 & 6 & 6 & 7 & 8 & 9 & 8 & 8 & 7 & 5 & 5 & 7 & 6
\end{array}\right]
$$

Result of the grey coefficient of all indexes and whitenization weight coefficient are presented in the table 
Table 4. the weight of indexes

\begin{tabular}{|c|c|c|c|c|c|c|c|c|c|}
\hline$\underbrace{\text { Grey }}_{\text {Coefficient }}$ & $\mathrm{e}=\mathbf{2}$ & $e=3$ & $e=4$ & sum & $\begin{array}{c}\text { Grey } \\
\text { Weights }\end{array}$ & $e=1$ & $\mathrm{e}=2$ & $e=3$ & $e=4$ \\
\hline$X_{111 e}$ & 4.29 & 2.00 & 0.00 & 10.73 & $\mathbf{R}_{111}$ & 0.4140 & 0.3996 & 0.1863 & 0.0000 \\
\hline $\mathbf{X}_{112 \mathrm{e}}$ & 3.86 & 1.40 & 0.00 & 10.04 & $\mathbf{R}_{112}$ & 0.4760 & 0.3845 & 0.1395 & 0.0000 \\
\hline $\mathbf{X}_{121 \mathrm{e}}$ & 4.71 & 3.40 & 0.00 & 11.78 & $\mathbf{R}_{121}$ & 0.3112 & 0.4002 & 0.2886 & 0.0000 \\
\hline$X_{122 \mathrm{e}}$ & 4.43 & 3.43 & 0.33 & 11.63 & $\mathbf{R}_{122}$ & 0.2961 & 0.3807 & 0.2948 & 0.0284 \\
\hline $\mathbf{X}_{131 \mathrm{e}}$ & 4.57 & 3.60 & 0.33 & 12.06 & $\mathbf{R}_{131}$ & 0.2949 & 0.3792 & 0.2986 & 0.0274 \\
\hline $\mathbf{X}_{132 \mathrm{e}}$ & 4.57 & 3.60 & 0.33 & 12.06 & $\mathbf{R}_{132}$ & 0.2949 & 0.3792 & 0.2986 & 0.0274 \\
\hline $\mathbf{X}_{211 \mathrm{e}}$ & 4.29 & 2.00 & 0.00 & 10.73 & $\mathbf{R}_{211}$ & 0.4140 & 0.3996 & 0.1863 & 0.0000 \\
\hline $\mathbf{X}_{212 \mathrm{e}}$ & 4.29 & 2.00 & 0.00 & 10.73 & $\mathbf{R}_{212}$ & 0.4140 & 0.3996 & 0.1863 & 0.0000 \\
\hline $\mathbf{X}_{221 \mathrm{e}}$ & 4.43 & 2.20 & 0.00 & 10.96 & $\mathbf{R}_{221}$ & 0.3953 & 0.4041 & 0.2007 & 0.0000 \\
\hline$X_{222 e}$ & 4.57 & 2.40 & 0.00 & 11.19 & $\mathbf{R}_{222}$ & 0.3772 & 0.4083 & 0.2144 & 0.0000 \\
\hline $\mathbf{X}_{231 e}$ & 3.86 & 1.40 & 0.00 & 10.04 & $\mathbf{R}_{231}$ & 0.4760 & 0.3845 & 0.1395 & 0.0000 \\
\hline $\mathbf{X}_{232 \mathrm{e}}$ & 4.14 & 1.80 & 0.00 & 10.50 & $\mathbf{R}_{232}$ & 0.4340 & 0.3945 & 0.1715 & 0.0000 \\
\hline $\mathbf{X}_{233 \mathrm{e}}$ & 3.86 & 1.40 & 0.00 & 10.04 & $\mathbf{R}_{233}$ & 0.4760 & 0.3845 & 0.1395 & 0.0000 \\
\hline $\mathbf{X}_{311 \mathrm{e}}$ & 4.71 & 3.00 & 0.00 & 11.60 & $\mathbf{R}_{311}$ & 0.3353 & 0.4061 & 0.2586 & 0.0000 \\
\hline $\mathbf{X}_{312 \mathrm{e}}$ & 4.57 & 2.80 & 0.00 & 11.37 & $\mathbf{R}_{312}$ & 0.3518 & 0.4019 & 0.2463 & 0.0000 \\
\hline $\mathbf{X}_{321 \mathrm{e}}$ & 4.43 & 2.20 & 0.00 & 10.96 & $\mathbf{R}_{321}$ & 0.3953 & 0.4041 & 0.2007 & 0.0000 \\
\hline $\mathbf{X}_{322 \mathrm{e}}$ & 3.86 & 1.40 & 0.00 & 10.04 & $\mathbf{R}_{322}$ & 0.4760 & 0.3845 & 0.1395 & 0.0000 \\
\hline $\mathbf{X}_{323 \mathrm{e}}$ & 4.43 & 3.80 & 0.33 & 12.00 & $\mathbf{R}_{323}$ & 0.2870 & 0.3690 & 0.3166 & 0.0275 \\
\hline $\mathbf{X}_{331 \mathrm{e}}$ & 4.29 & 4.00 & 0.33 & 11.95 & $\mathbf{R}_{331}$ & 0.2790 & 0.3587 & 0.3348 & 0.0276 \\
\hline$X_{332 \mathrm{e}}$ & 4.43 & 3.80 & 0.33 & 12.00 & $\mathbf{R}_{332}$ & 0.2870 & 0.3690 & 0.3166 & 0.0275 \\
\hline $\mathbf{X}_{333 \mathrm{e}}$ & 4.57 & 2.80 & 0.00 & 11.37 & $\mathbf{R}_{333}$ & 0.3518 & 0.4019 & 0.2463 & 0.0000 \\
\hline $\mathbf{X}_{411 \mathrm{e}}$ & 4.29 & 2.00 & 0.00 & 10.73 & $\mathbf{R}_{411}$ & 0.4140 & 0.3996 & 0.1863 & 0.0000 \\
\hline$X_{412 \mathrm{e}}$ & 3.71 & 1.20 & 0.00 & 9.80 & $\mathbf{R}_{412}$ & 0.4989 & 0.3786 & 0.1225 & 0.0000 \\
\hline
\end{tabular}


Table 4. Cont. the weight of indexes

\begin{tabular}{|c|c|c|c|c|c|c|c|c|c|}
\hline $\mathbf{X}_{421 \mathrm{e}}$ & 4.00 & 1.60 & 0.00 & 10.27 & $\mathbf{R}_{421}$ & 0.4545 & 0.3896 & 0.1558 & 0.0000 \\
\hline $\mathbf{X}_{422 \mathrm{e}}$ & 4.57 & 2.40 & 0.00 & 11.19 & $\mathbf{R}_{422}$ & 0.3772 & 0.4083 & 0.2144 & 0.0000 \\
\hline $\mathbf{X}_{423 \mathrm{e}}$ & 4.43 & 3.80 & 0.33 & 12.00 & $\mathbf{R}_{\mathbf{4 2 3}}$ & 0.2870 & 0.3690 & 0.3166 & 0.0275 \\
\hline $\mathbf{X}_{511 \mathrm{e}}$ & 3.86 & 4.60 & 1.00 & 12.46 & $\mathbf{R}_{511}$ & 0.2408 & 0.3096 & 0.3693 & 0.0803 \\
\hline$X_{512 \mathrm{e}}$ & 3.86 & 4.60 & 1.00 & 12.46 & $\mathbf{R}_{512}$ & 0.2408 & 0.3096 & 0.3693 & 0.0803 \\
\hline $\mathbf{X}_{521 \mathrm{e}}$ & 4.86 & 2.80 & 0.00 & 11.66 & $\mathbf{R}_{521}$ & 0.3431 & 0.4168 & 0.2401 & 0.0000 \\
\hline$X_{522 \mathrm{e}}$ & 4.71 & 3.40 & 0.00 & 11.78 & $\mathbf{R}_{522}$ & 0.3112 & 0.4002 & 0.2886 & 0.0000 \\
\hline
\end{tabular}

Part of the calculation process is as follows:

Land Utilization $R_{111}=\left[\begin{array}{llll}0.4142 & 0.3994 & 0.1864 & 0\end{array}\right] \mathrm{T}$

Land for Greening $R_{112}=\left[\begin{array}{llll}0.4761 & 0.3844 & 0.1395 & 0\end{array}\right] \mathrm{T}$

And then a comprehensive evaluation of the secondary indicators, $B_{i j}=w_{i j} * R_{i j}$, take Planning and Ecology as an example:

$$
\begin{aligned}
B_{11}= & (0.4565,0.5435) *\left[\begin{array}{llll}
0.4142 & 0.3994 & 0.1864 & 0 \\
0.4761 & 0.3844 & 0.1395 & 0
\end{array}\right] \\
& =(0.4478,0.3912,0.1609,0)
\end{aligned}
$$

Create a whitenization weight coefficient matrix for the second-level index based on ${ }_{i j}$ :

$$
\left[\begin{array}{llll}
0.4478 & 0.3912 & 0.1609 & 0.0000 \\
0.2990 & 0.3845 & 0.3027 & 0.0138 \\
0.2949 & 0.3792 & 0.2986 & 0.0274
\end{array}\right]
$$

and then give a comprehensive evaluation of the first-level index, $B_{i}=w_{i} * R_{i}$

$$
\begin{aligned}
B_{1} & =(0.3332,0.3591,0.3077) *\left[\begin{array}{llll}
0.4478 & 0.3912 & 0.1609 & 0.0000 \\
0.2990 & 0.3845 & 0.3027 & 0.0138 \\
0.2949 & 0.3792 & 0.2986 & 0.0274
\end{array}\right] \\
& =(0.3473,0.3851,0.2542,0.0134)
\end{aligned}
$$

Build a whitenization weight coefficient matrix for the first-level index according to

$$
B_{i}:\left[\begin{array}{llll}
0.3473 & 0.3851 & 0.2542 & 0.0134 \\
0.4209 & 0.3978 & 0.1813 & 0.0000 \\
0.3445 & 0.3884 & 0.2577 & 0.0094 \\
0.4197 & 0.3885 & 0.1875 & 0.0043 \\
0.2843 & 0.3592 & 0.3163 & 0.0401
\end{array}\right]
$$


The final comprehensive evaluation results:

$$
\begin{gathered}
B \text { 总 }=\left(\begin{array}{lllll}
0.2 & 0.25 & 0.25 & 0.2 & 0.1
\end{array}\right) *\left[\begin{array}{lllll}
0.3473 & 0.3851 & 0.2542 & 0.0134 \\
0.4209 & 0.3978 & 0.1813 & 0.0000 \\
0.3445 & 0.3884 & 0.2577 & 0.0094 \\
0.4197 & 0.3885 & 0.1875 & 0.0043 \\
0.2843 & 0.3592 & 0.3163 & 0.0401
\end{array}\right] \\
=\left(\begin{array}{llll}
0.3732 & 0.3872 & 0.2297 & 0.0099
\end{array}\right)
\end{gathered}
$$

The green building comprehensive evaluation value is:

$$
W=B \times C^{T}=\left[\begin{array}{llll}
0.3732 & 0.3872 & 0.2297 & 0.0099
\end{array}\right] *\left[\begin{array}{l}
9 \\
7 \\
5 \\
3
\end{array}\right]=7.2474
$$

The evaluation evaluation index score of the four sections, the comprehensive evaluation value in the three-star range $[9,7)$, it can be assessed as a green campus.

\section{Conclusions}

The AHP and Multi-Level Gray Comprehensive Evaluation Method are used to conduct post project evaluation of the green campus. In the process of weight distribution, the satisfaction of the users is taken into account, which can quantify the qualitative problems, so the index system is more scientific and comprehensive. The appliance of multi - level gray comprehensive evaluation method in analyzing the data improved the accuracy of the final result, which also provided theoretical and practical support for the post project evaluation of the green campus.

\section{Acknowledgements}

This work was financially supported by Energy Conservation Standard For Building Of Jiangsu Province Project and Undergraduate Training Programs for Innovation and Entrepreneurship.

\section{References}

[1] Shi Tie-mao ,Li Shuo.The construction strategy of green campus — taking the campus construction of shenyang jianzhu university for example $[\mathrm{C}] / /$ Invitation Report of the 21 st National Conference on Structural Engineering,2012.

[2] Gan Yufeng. Study on POE of the Building Energy Saving Demonstration Project[D].Master 's degree thesis of Chongqing University,2011.

[3] Hu Sheng huang.A Multilevel Grey Evaluation Method for Subjective Index APPraisal [J] .System Engineering Theory and Practice, 1996(1):12.

[4] Wang Qiang, Feng Xiaoping, Tian Bei,Chen Yingling.Evaluation of Green University Stars Based on Multi - level Gray Evaluation Method,Sichuan Building Science,1008 - 1933(2014) 06288-04.

[5] Deng Julong.Gray system basic method [M] ,wuhan: Huazhong Institute of Technology Press, 1987. 